\title{
Music and Literature: Ethel Smyth, Virginia Woolf, and \\ "The First Woman to Write an Opera"
}

\author{
CHRISTOPHER WILEY
}

I'm awfully proud — thats not the right phrase — that you've started again on the autobiography, partly owing to me. I was thinking the other night that there’s never been a womans autobiography. Nothing to compare with Rousseau. Chastity and modesty I suppose have been the reason. Now why shouldnt you be not only the first woman to write an opera, but equally the first to tell the truths about herself? Isnt the great artist the only person to tell the truth? I should like an analysis of your sex life. As Rousseau did his. More introspection. More intimacy. I leave it to you; for as you see I cant make my pen take my ply this cold morning. - Letter from Virginia Woolf to Ethel Smyth, 24 December $1940 .^{1}$

Ethel Smyth’s (1858-1944) later life was significantly enlivened by her frequent contact with Virginia Woolf (1882-1941), from which a fruitful, if sometimes strained, friendship blossomed that was curtailed by Woolf's suicide in March 1941. By the time of their first meeting in February 1930, Smyth, having overcome substantial opposition to her chosen career path and challenged traditional notions of the place of women within music composition internationally, had written six operas, a Mass, and many other chamber, orchestral, and vocal works, and was working on what was to be her last major composition, her oratorio The Prison. ${ }^{2}$ Her increasing 
deafness may have compelled her to develop a secondary career as writer of memoirs, biographical and other sketches, as well as polemical essays, ${ }^{3}$ but music remained her greatest passion, her first "string," and her "real love." ${ }^{4}$ Woolf had similarly attained the professional success that established her as a pioneering modernist by 1930, having published the first six of her nine novels, as well as many newspaper articles, book reviews, and other essays (some of which were collected in her anthology The Common Reader, the first volume of which had appeared in 1925), including her foundational feminist polemic, A Room of One’s Own (1929). ${ }^{5}$ Investigation of the continuing intellectual dialogue that took place between these two pathbreaking artists enriches our understanding of wider differences between the disciplines of music and literature, their histories, canons, and art, as well as revealing much about the underrepresentation of women that both felt acutely, and against which they campaigned fervently in their writings.

One product of this dialogue was Woolf's letter of 24 December 1940, written toward the end of their decade-long association. Her words have typically been cited by scholars as evidence either of the inherent difference between autobiographies merely written by women and a woman's autobiography that delineated faithfully a complete existence, or of her belief that the latter could not be achieved through conventional male paradigms and therefore had the potential to elude classification as such. ${ }^{6}$ Woolf's strange claim that no women's autobiographies had been written by 1940 would seem, at face value, to stand up to little scrutiny. The very suggestion can hardly have been received positively, given that it was directed to someone who had recently published her fourth chronological volume of memoirs, which Woolf had read in the July of that year, ${ }^{7}$ not to mention several other collections of auto/biographical episodes and a travel-book. ${ }^{8}$ However, as I have explored in a previous study titled ““When a woman speaks 
the truth about her body': Ethel Smyth, Virginia Woolf, and the Challenges of Lesbian Auto/biography,” Woolf's continual criticism of Smyth's manifold literary undertakings, when read in conjunction with her biographical theories and feminist critiques, would seem to indicate her belief that Smyth's writings could not be positioned as genuine women's autobiographies. ${ }^{9}$ Woolf held that her friend's procedure of narrating stories exclusively relating to herself was overly egotistical, insisting on her own individuality through repeated use of the first-person singular; close reading of A Room of One's Own identifies that she viewed this practice as phallocentric. ${ }^{10}$ By contrast, Woolf progressively edited out her own authorial voice from her texts, substituting those of multiple fictitious narrators in its place by way of endeavoring to reflect women’s multifaceted nature more accurately.

The excerpt from Woolf's correspondence quoted above provides a crucial piece in the epistemological jigsaw, in that Smyth’s perceived failure to relate faithfully her experiences as a woman in her autobiographical works is directly aligned with her omission to recount the truth about her sex life. Suzanne Raitt has commented that “[Smyth’s] published writing, although absolutely frank about the passion and the romance of her feelings for women, remains resolutely silent about the sexual aspects," ${ }^{11}$ which is all the more revealing if one considers that an understanding of her sexuality is fundamental to an appreciation of her life and work. Rather than adopting Woolf's more pluralistic outlook, however, Smyth continued to produce irredeemably self-centered narratives, preferring the masculine autobiographical model; perhaps she believed that this strategy offered the best available means for her to ingratiate herself within music's strongly male-dominated canons. Thus, judged by Woolf's criteria, she did not represent herself authentically as a woman and a lesbian in her texts. ${ }^{12}$ 
To probe further into the relationship between the two disparate artistic disciplines under scrutiny, consideration of Woolf's curious statement from the point of view of music and musicology, rather than that of literature, proves illuminating. A parallel reading of the published texts and private correspondence of Smyth and Woolf may explicate the other far-reaching claim made in the course of the oft-quoted passage of the epigraph; for Woolf did not merely suggest that there had never been a woman's autobiography, but also that Smyth was the first woman to compose an opera. ${ }^{13}$ The latter factual error has, quite understandably, often been overlooked by those scholars whose interest lies primarily within the realms of Woolf studies or women's autobiography. Although Smyth had surprisingly little to say about other women composers, she did discuss one particular figure at some length, her older contemporary Augusta Holmès (18471903), whose operas predated Smyth’s own.

Reading Smyth on Holmès, Woolf should have recognized the inexactitude of her assertion. Woolf's words may instead be understood to reflect the view that though Smyth's autobiographies subscribed to traditional, masculine paradigms and hence did not represent her womanly experiences fully, her operas evinced a sympathy with her feminist and lesbian proclivities that is absent from her memoirs. ${ }^{14}$ After all, Smyth was keenly aware of the sexual prejudice she experienced throughout her compositional career, as well as the heavily gendered criticism prompted by her music. ${ }^{15}$ Modern hermeneutical readings of some of Smyth’s works through the lens of gender and sexuality, notably by Elizabeth Wood, ${ }^{16}$ have contributed weight to these arguments in two main areas: first, bringing to light her resistance to, and subversion of, gendered conventions established within music, such as her undermining and reappropriation of the principles of sonata form and her preference for the mezzo-soprano (rather than soprano) voice for operatic heroines; and second, calling attention to Smyth's practice of inscribing 
herself, and others, into her music, by employing strategies analogous to those by which contemporary lesbian writers (including Woolf) eluded the censor by couching autobiography in the guise of thinly-veiled fictional narrative. Coming at such a pivotal juncture in her correspondence, Woolf may have had a deeper meaning in mind in making this claim, one inextricably linked to her strikingly bold statement on women's autobiography.

Investigation of Woolf in relation to music has increased in recent years, ${ }^{17}$ with several scholars focusing specifically on aspects of her fascinating association with Smyth. ${ }^{18}$ That Woolf is invariably at the center of inquiry has led certain important aspects of the counterpoint between the two artists to be overlooked, not least the ways that Smyth, as an authority on music, directly influenced Woolf's own writings. ${ }^{19}$ By shifting the focus to Smyth, this essay explores issues of specifically musicological relevance, such as the reasons why a woman composer might have constructed herself as a solitary figure, even within contexts in which the number of females actively creating music was recognizably growing. Smyth implicitly presented herself as standing apart from the improving status of women composers that was modestly starting to assert itself during her lifetime. By the late nineteenth and early twentieth centuries, music history chronicled a number of precedents for women writing opera, as well as the activities of sundry female contemporaries with whom Smyth was in direct contact.

A comprehensive scrutiny of Smyth's literary output reveals that its coverage of women composers other than herself was quite restricted and fitful, and often cast in a somewhat dismissive, unflattering vein, with telling traces of revisionism evident between her earlier and later writings. Smyth thus presented Woolf with an incomplete impression of the extent of women's contributions to the field; understandably, Woolf echoed her friend's portrayal of herself as a unique figure. Later sections of this essay examine arguments advanced by Smyth 
concerning the different opportunities afforded to aspiring (female) professionals within music and literature as well as the obstacles exclusively posed by music criticism. Smyth's selfcentered feminist writings will be compared with Woolf's more inclusive offerings in order to investigate the junctures at which their inquiries corresponded and diverged, yielding insights into the broader relationships between their respective disciplinary standpoints. Woolf's possible motives for not probing the underrepresentation of women in music at greater length in Three Guineas (1938) will also be discussed, as this polemical successor to A Room of One's Own sheds additional light upon her intellectual relationship with Smyth.

Woolf's ostensibly dismissive attitude toward Smyth's writings can be read within the wider context of her general opinion of her friend's literary gifts. Even in Smyth's earliest autobiographical productions, the two-volume Impressions that Remained, Woolf found her to be colloquial, frank, and egotistical. Woolf exercised tact when she articulated her thoughts publicly in The New Statesman, in which she touched upon Impressions that Remained in the course of reviewing Smyth's second extended literary offering, the miscellany of autobiographical episodes titled Streaks of Life. ${ }^{20}$ But privately she confided to Lytton Strachey, “It's a pity she can’t write; for I don’t suppose one could read it again. But it fascinates me all the same.”21 When she came to know Smyth, Woolf's judgment mellowed a little: Impressions that Remained was described as "fascinating," a "masterpiece," and even "immortal”- at least when she was addressing its author. ${ }^{22}$ Though her criticisms of Smyth’s drafts could be harsh, Woolf persistently encouraged her friend to continue writing autobiography. ${ }^{23}$ Woolf was so delighted that Smyth's third chronological volume of memoirs, As Time Went On..., had been tentatively dedicated to her that she even attempted to persuade the composer to repeat the gesture with a subsequent book. ${ }^{24}$ At the same time, Woolf's words occasionally call into 
question just how carefully she paid attention to Smyth's work. After having known the author for nearly a decade, Woolf wrote of rewarding the nighttime hours when she was woken by airplanes by reading "Ethel Smyth—Gleams of Memory." ${ }^{25}$ That was, of course, not the title of one of Smyth's publications. ${ }^{26}$

Woolf's attitude toward Smyth's compositions was colored by a similar sense of ambivalence. As noted at the beginning of this essay, in one hastily written letter she rather generously described Smyth as the first woman to compose an opera; ${ }^{27}$ elsewhere Woolf expressed indifference toward Smyth's music and an uncertainty as to her wider place in music history. A little under a year after their first meeting, Woolf confided to her diary:

I suspect [Smyth's] music is too literary—too stressed—too didactic for my taste. But I am always impressed by the fact that it is music-I mean that she has spun these coherent chords harmonies melodies out of her so practical vigorous, strident mind. What if she should be a great composer? This fantastic idea is to her the merest commonplace: it is the fabric of her being. As she conducts, she hears music like Beethoven’s. ${ }^{28}$

Woolf's observations, made after having attended a rehearsal of The Prison, were perceptive. Smyth had been trained in the Teutonic traditions of the nineteenth century (Woolf had previously noted in her diary that "they say she writes music like an old dryasdust German music master, ${ }^{29}$ ), and she did aspire to Beethovenian heights. In her formative years, Smyth’s interest in music was kindled by her mother and then, more dramatically, by a governess who had studied at the Leipzig Conservatory, whose example inspired Smyth to enroll in the same 
institution in the late 1870s. At the Conservatory, she studied under Carl Reinecke and others, before becoming disillusioned and leaving to take lessons with Heinrich von Herzogenberg. She settled in Germany for over a decade before circumstances compelled her to return home; during that time she became acquainted with some of the country's most renowned musical personages including Brahms, about whom she later wrote at length, ${ }^{30}$ and Clara Schumann. In Impressions that Remained, Smyth was to cite the discovery of Beethoven's music as a major factor that guided her steps toward Germany. ${ }^{31}$ Beethoven remained one of her favorite composers thereafter, and, as Woolf's words hint, exerted an influence on her music. As Jane Bernstein has observed, there are notable similarities between the style and character of Beethoven's iconic Missa Solemnis (1819-23) and Smyth’s own Mass (1891), a large-scale setting of the Ordinary that, like Beethoven's work, is cast in D major. ${ }^{32}$ Comparisons between the two scores likewise permeate the analysis of Smyth's Mass by Donald Francis Tovey. ${ }^{33}$

Through her study in Germany and her admiration for Beethoven and Brahms, Smyth was well versed in the conventions of the musical patriarchy she was to subvert in her own output. At the heart of that œuvre lie the operas that Kathleen Abromeit has collectively described as "an almost unbelievable accomplishment for a woman composer of the day.”34 Despite Smyth's achievement and Woolf's claim, Smyth's operas were hardly the first to have been composed by a woman. The disjointed history of women writing opera can be traced back to the virtual beginnings of the genre in Italy at the turn of the seventeenth century. The first female operatic composer is generally acknowledged to have been Francesca Caccini (1587?1641), the daughter of Giulio Caccini, whose Euridice (1600-1601) was the first ever published opera. ${ }^{35}$ As Suzanne Cusick has shown through critical reading of the work, Francesca Caccini's 
one surviving opera, La liberazione di Ruggiero dall'isola d'Alcina (1625), may indeed be seen to be true to her womanhood. ${ }^{36}$

Francesca Caccini’s precursory example may have been exceptional, but it was by no means the only one. Others included Elisabeth-Claude Jacquet de la Guerre (?1665-1729) and Maria Theresia von Paradis (1759-1824), neither of whom had been entirely forgotten to music history; and as a study by Jacqueline Letzter and Robert Adelson has demonstrated, women such as Isabelle de Charrière (1740-1805) had been notably active in the writing of opera in late eighteenth- and early nineteenth-century France. ${ }^{37}$ It is highly unlikely that Woolf—or, for that matter, Smyth—knew anything about Caccini or any of these precursors; in the absence of evidence from primary sources, their awareness of earlier women composers is conjectural at best. However, Woolf was by no means wholly ignorant of the field of music, nor of the extent of the sexual discrimination within that profession even during her own day. In October 1920, nearly a decade before she met Smyth, Woolf had drawn upon her case in an epistolary exchange with literary editor Desmond MacCarthy (writing under the pseudonym “Affable Hawk”) in The New Statesman, by way of demonstrating the challenges encountered by women who endeavored to pursue a musical career. ${ }^{38}$ If proof be needed that she could cite contemporary woman composers other than Smyth, A Room of One's Own contains a barbed response to critic Cecil Gray’s misogynistic comments concerning Les Six member Germaine Tailleferre (1892-1983):

The woman composer stands where the actress stood in the time of Shakespeare. Nick Greene ... said [in Woolf's fictitious story] that a woman acting put him in mind of a dog dancing. [Samuel] Johnson repeated the phrase two hundred years later of women preaching. And here, I said, opening a book about music, we have 
the very words used again [by Cecil Gray] in this year of grace, 1928, of women who try to write music. "Of Mlle. Germaine Tailleferre one can only repeat Dr. Johnson’s dictum concerning a woman preacher, transposed into terms of music. 'Sir, a woman's composing is like a dog's walking on his hind legs. It is not done well, but you are surprised to find it done at all.’” So accurately does history repeat itself. ${ }^{39}$

As Peter Jacobs has noted, Woolf received a basic musical education in her childhood, and enjoyed listening to music throughout her life. ${ }^{40}$ She was also distantly related to Vaughan Williams, a champion of women composers during his time at the Royal College of Music, through his first wife Adeline, a cousin on Woolf's mother's side. Woolf's writings attest that opera was a particular preoccupation. She published two essays on the subject in The Times in $1909 ;{ }^{41}$ and as scholars such as Jane Marcus and Emma Sutton have recently shown, her novels reflect a thorough understanding of the plots, structures, and conventions of certain canonical works, including Wagnerian music drama (not least Der Ring des Nibelungen) and Mozart's Die Zauberflöte. ${ }^{42}$ Her knowledge of the former, which is also demonstrated by her two Times articles, is especially relevant to the present inquiry given the patent Wagnerian influences reflected in Smyth’s early operatic œuvre.

Yet the passage of Woolf's correspondence quoted in the epigraph offers no indication that the author was aware that Smyth might have had any antecedents among female opera composers. As noted, Smyth's own writings would have provided Woolf with only a limited idea of women's activity in this field. Although Smyth urged for solidarity among female musicians, she generally glossed over the existence of women composers past and present, only mentioning 
them in passing. In her essay “A Final Burning of Boats” (published in 1928 in the book of the same title), for example, there is a brief allusion to Dorothy Howell (1898-1982), in the context of her exclusion from the then recently-published third edition of Grove's Dictionary of Music and Musicians (1927-28). ${ }^{43}$ However, Smyth diluted the force of her observation by declining to supply any further information about Howell, who, as a woman forty years her junior and at the outset of her musical career, had achieved only limited public recognition. ${ }^{44}$ One reason for Smyth's having mentioned Howell at all lay in the potential for a pointed comparison with a male near-namesake, Herbert Howells. Aside from rhetoric, it is unclear why Smyth chose Howell as the solitary example of a female composer whom she held to have been wrongly omitted from this landmark text. There were certainly others she could have cited in support of her arguments. Similarly ambiguous is Smyth's description of Howell as “composer and Professor at the Royal Academy of Music,” which suggests that a case for her inclusion in a music dictionary could be made as much on the basis of her teaching as for any other reason. ${ }^{45}$ On the basis of Smyth's words, an uncharitable reader might have been led to suppose that Howell was a teacher rather than a composer by profession.

One of the most famous female composers of all time, Clara Schumann (1819-96), surfaces on a number of different occasions in Smyth's memoirs, especially when the two women became acquainted during Smyth’s time studying in Germany. Yet Smyth’s memoirs typically discuss Clara as an acclaimed concert pianist, and as the wife of Robert Schumann and mother of his children, without alluding to her compositional activity. ${ }^{46}$ The sole exception occurs in a letter Smyth wrote to her mother in April 1878, quoted in Impressions that Remained: 
I went to Breitkopf and Haertel—-the music publishers par excellence in the world. The nephew, who conducts the business, Dr. Hase, I know very well and he is quite one of the most charming men I ever met.... Well, he began by telling me that songs had as a rule a bad sale—but that no composeress had ever succeeded, barring Frau [Clara] Schumann and Fräulein [Fanny] Mendelssohn, whose songs had been published together with those of their husband and brother respectively. He told me that a certain Frau [Josephine] Lang had written some really very good songs, but they had no sale. I played him mine ... and he expressed himself very willing to take the risk and print them. But would you believe it, having listened to all he said about women composers, and considering how difficult it is to bargain with an acquaintance, I asked no fee! ${ }^{47}$

Given Smyth's tendency to pass over other examples of women composers, this passage is particularly fascinating for its mention not just of Clara Schumann's creative musical endeavors but also those of Fanny Mendelssohn (1805-47) and Josephine Lang (1815-80). What is most telling about this allusion to a total of three antecedents is that it occurs not in the autobiographical narrative itself, but in the correspondence that she was wont to reproduce wholesale in dedicated sections of her volumes. Though her contemporary personal documents did at least acknowledge the compositional activities of women aside from herself, the story that she recounted retrospectively for publication painted a somewhat different picture. ${ }^{48}$ Nonetheless, in this instance, the fact of Smyth's having several precursors is presented as actually inhibiting her as she sought to publish her own music. The representative of Breitkopf \& Härtel with whom she spoke, Dr. Hase, noted that the reason the songs of Fanny Mendelssohn 
and Clara Schumann had entered into print was that they appeared in the same volume as those of celebrated male composers to whom they were related. ${ }^{49}$ That was obviously an option unavailable to Smyth. Moreover, the lack of commercial success of Josephine Lang's published music is couched as a precedent that was potentially harmful to her. Subsequent history suggests that this assessment was not necessarily accurate: in 1882, just four years after Smyth’s visit to their offices, Breitkopf \& Härtel were to issue a posthumous collection of forty songs by Lang. This fact alone provides an indication as to whether such a venture would have been considered commercially viable. Taking Smyth’s account at face value, however, the publisher's representative ranked highly those of Lang’s songs that had appeared in print by 1878; the inescapable implication of his words—notwithstanding the point that songs generally sold poorly—is that their failure to attract buyers may have been connected to the composer's gender. Having heard Dr. Hase's comments on the risk involved in publishing the music of women composers, Smyth felt unable to bargain for a fee for her music, and so lost out financially as well.

In the whole of Smyth's literary output, as noted, only one female composer received extensive discussion. Augusta Holmès was the subject of a dedicated essay (originally written in July 1921) in A Final Burning of Boats, which provided a sketch of her character, an evaluation of her music, and an account of Smyth’s visits to her in 1900 and 1902, the first of which was later retold in What Happened Next..$^{50}$ It is these sections of Smyth's writings, if any, that would have alerted Woolf that Smyth was not the first woman ever to have written an opera. Holmès was over ten years older than Smyth, and her four operas were all completed by 1884, roughly a decade before Smyth had written her first. ${ }^{51}$ Though only Holmès’s La montagne noire was actually performed, she had at least brought an opera to the stage in advance of Smyth, whose 
Fantasio was premiered in Weimar in 1898, three years after Holmès’s work had been received (coolly) at the Paris Opéra. But despite writing about Holmès at such length, Smyth did not always appear well disposed toward her. The portrait she painted of her senior contemporary is hardly a flattering one; Holmès, at that time middle aged and ailing, is introduced in What Happened Next as "a convalescent arrayed in a red flannel dressing-gown ... short and fat, her red hair powdered white ... and her white face, helped out with black, red, and white, vigorously and wildly applied, as by one who could not be bothered to use a looking-glass and preferred doing her face 'by heart." ${ }^{52}$ And, though Smyth enjoyed and even promoted some of her music, her description of her as "the nearest approach to a large-scale woman composer that the world had yet seen” could reasonably be construed as dismissive. ${ }^{53}$ Her views on La montagne noire, meanwhile, left little doubt as to exactly how highly she rated her senior contemporary as a composer of opera:

much of the music was student's work. But, child though she must have been when most of it was written, she invariably rose to the big situations, and given her strong dramatic instinct and the pages upon pages of warm, beautiful, melodious music in it, a second opera from her pen might have been a masterpiece. But it was never to be written. ${ }^{54}$

Putting aside her pointed comments about the putative immaturity of La montagne noire, both this and other of Smyth’s observations led the reader to believe that it was Holmès's first and only opera. But Smyth, who had met Holmès on two separate occasions and knew much about her both by reputation and from mutual friends, would surely have been aware that this 
was not the case. Even more startling is her disparaging remark "Of her opera I only heard a part; but knowing what I do about the difficulties of opera composers, especially plus the handicap of sex, the astonishing fact about it was that it existed at all."55 In A Room of One's Own, Woolf reproached Cecil Gray for making a similar pronouncement about Germaine Tailleferre, and the similarity of Smyth's assessment to that of Gray illuminates her attitude toward Holmès. Having read A Final Burning of Boats, ${ }^{56}$ Woolf would have disapproved of Smyth’s evaluation; this may provide a reason why it is the one of the least discussed of Smyth's volumes in their entire correspondence.

Even more revealing is the shift in Smyth's presentation of the nature of her relationship to Holmès between her earlier article and Holmès's appearance in What Happened Next some two decades later. In A Final Burning of Boats, Smyth had identified that she had sought her initial meeting with Holmès on the grounds that she was "a fellow-struggler in the thicket of opera”; the pretext for her second visit was provided by Smyth’s desire to talk about her opera Der Wald, which was then being staged in London. ${ }^{57}$ Smyth's implication was that Holmès was a "fellow-struggler" not just because they were both opera composers, but also because they were both women who had endured hardship in the course of securing stage productions of their works. ${ }^{58}$ In contrast, Smyth’s subsequent account of their meeting in What Happened Next included a codetta absent from the original: “When we parted after three hours' ardent conversation, we embraced with fervour. I . . f felt we really were friends. Just at the end [of the meeting] there was a touch of symposium; 'Adieu chère collègue,' she said—a remark I pretended not to hear." ${ }^{59}$ Why was it so important to Smyth to be seen as ignoring Holmès’s parting words? By her own admission, the two women had enjoyed an amiable conversation. Her earlier essay had been titled “Augusta Holmès, Pioneer” (ironically, using the exact same term 
with which Woolf would describe Smyth ten years later in a speech to be quoted presently). But why should somebody Smyth deemed to be a "fellow-struggler" in 1921 not also be considered her colleague in 1940 ? Just as she seems to have shifted her ground on other women composers between her correspondence written in the late 1870s and Impressions that Remained, Smyth ultimately appears to have chosen not to regard Holmès as an ally in her crusade to overcome prejudice within the male-dominated music profession. ${ }^{60}$ As with Josephine Lang, the fact of Smyth's having encountered another instance of a woman who had turned her attentions toward music composition—and even, in Holmès's case, the writing of opera—was at best a coincidence, and at worst a hindrance.

Smyth’s writings often retail the discrimination she experienced as a woman composer, and how she and her work suffered at the hands of the coterie of power-wielding decisionmakers to whom she collectively referred as the Inner Circle, the Group, the Elders, or the Machine. In view of the strength of her feeling that the musical patriarchy was conspiring against her, Smyth's apparently prejudicial attitude toward fellow female composers might seem paradoxical. Yet, if the words Woolf quoted from Cecil Gray were any reflection of prevailing male opinion of women composers, it is unsurprising that Smyth took measures to distance herself from other examples of "women who try to write music" (to borrow Woolf's description), and hence from the stigma that came with being bracketed in that denigrated category. She did not want to be seen as a vamp like Holmès or a salon composer like Lang. Smyth insisted on being evaluated on her own terms as equal to men; she did not want feminine allies who would have been considered weak. She viewed herself only as the precursor of "a future chain of great women composers. ${ }^{, 61}$ It appears likely that she isolated herself from female counterparts in an attempt to insinuate herself into the otherwise masculine domain of musical 
canon. This strategy succeeded to a remarkable extent. While she lamented that "the public ... mildly says from time to time: 'Strange that there are no great women composers!,",62 her own writings contributed little to addressing this imbalance lest it affect the status of her own music. Who can blame her?

Woolf perpetuated Smyth’s self-portrait as a unique phenomenon distinct from any previous female composers. At the event that was to be the pinnacle of their relationship, their joint presentation at the meeting of the London/National Society for Women's Service on 21 January 1931 on the subject of “Music and Literature,” Woolf paid homage to her friend as being “of the race of pioneers, of pathmakers ... [who] has gone before and felled trees and blasted rocks and built bridges and thus made a way for those who come after her." ${ }^{63}$ Woolf held that her own profession was the only one that had been available to women of earlier periods, in stark contrast to disciplines such as music and the visual arts. In Three Guineas, which had its origins in this speech, she wrote:

the profession of literature, to give it a simple name, is the only profession which did not fight a series of battles in the nineteenth century. . . . We cannot debar women from the use of libraries; or forbid them to buy ink and paper; or rule that metaphors shall only be used by one sex, as the male only in art schools was allowed to study from the nude; or rule that rhyme shall be used by one sex only as the male only in Academies of music was allowed to play in orchestras. ${ }^{64}$

Smyth confirmed Woolf's perception of the differences between their respective professions in terms of the possibilities they held for women. Her writings repeatedly express the 
opinion that the difficulties experienced by women in music were far greater than in the other creative arts. She drew specific comparison between music and literature, notably in her polemical essay "Female Pipings in Eden” (1933, from the volume of the same title), which included a chapter dedicated to the topic. ${ }^{65}$ Smyth’s embrace of this reasoning is understandable to the extent that her literary output may be regarded as self-serving. She knew well that she had a broader audience for her books than for her scores, and sought to stimulate public interest in her music through literary writings that were both entertaining and polemical ${ }^{66}$ Nonetheless, her activities within both spheres—-her first and second "strings" — meant that she was well qualified to comment upon the differences between them. Her arguments rest on such firm foundations that they cannot be dismissed merely on the grounds of authorial agenda. She held that it was eminently possible to teach oneself how to write literature, by reading privately, observing life, and recounting one’s experiences to friends; hence in earlier periods of history, "nobody could prevent women from writing novels on the sly." ${ }^{, 67}$ To Smyth’s mind, the book trade was "divinely simple": printing was comparatively cheap, hence publication carried limited financial risk; the sole mediator between author and public was the publisher; there was much more scope for books and authors to coexist amicably; and even if a particular novel did not find favor with the critics, members of the public could easily buy their own copies and decide for themselves. By baleful contrast, engraving music was expensive; performances of large-scale works could not be mounted without the mediation of publishers or copyists to reproduce the parts; conductors and their associated committees were primarily interested in performing the "old favourites” of the repertory, for fear of losing audiences and the financial support provided if they did not; and any new works that somehow found their way to the concert hall were often relegated to oblivion after a single performance. Given these obstacles, and the consequently 
limited room for contemporary composers in concert programs, Smyth contended that it was unsurprising that the musical establishment was governed by favoritism, string-pulling, and male solidarity. Her observations may be reinterpreted as reflecting the reality that there was significantly more space available for women within literary canons than those of music, where hegemonic rankings were therefore more tightly enforced.

Smyth's point about the significance of critical opinion, meanwhile, was addressed more fully in another essay in the same volume, "Where Musical Criticism Goes Astray." ${ }^{68}$ There she argued that anybody could repeatedly read a poem, view a painting, or even attend a play (typically given as a series of performances), but that public opinion on a new musical workpresentations of which were few and far between - lay to large extent in the soiled hands of the press. Smyth held that music critics were faced with a thorny task in that they were required to judge a given score on a single hearing. Further, they had to evaluate a new work on the basis of a performance that could be seriously flawed, without knowing whether the blame for any perceived faults lay with its composer or with an insensitive conductor, limited rehearsal time, or even the absence of necessary instruments. She cited a number of instances in recent music history in which the initial criticism had been negative of pieces subsequently recognized as masterpieces. Smyth believed that the press could never kill off a work that is "really alive," yet her view was that a dismissive critique might nevertheless "induce a state of suspended animation which may last longer than the life of the unfortunate composer.”69

Reading the output of Smyth and Woolf in tandem inevitably leads to speculations as to whether there was an element of competition between them, with their various writings implicitly responding to one another. ${ }^{70}$ Many of the views presented thus far are drawn from the intellectual fruits of their friendship: speeches they delivered on a shared platform; the literature 
that resulted from them; and essays passed from one to the other for comment prior to publication. ${ }^{71}$ A certain amount of tension did exist between the two women, even despite- or perhaps, precisely because of - their belonging to different eras, artistic disciplines, and sociopolitical backgrounds. If Smyth’s chapter in "Female Pipings in Eden” was intended to demonstrate how much more problematic the path to professional success was for a woman in music than in literature, then one of her principal comparators for the latter field was Woolf herself. An early draft of "Female Pipings in Eden" included references to Woolf, which so displeased the novelist that she recommended that Smyth remove them. Woolf went so far as to annotate Smyth's manuscript to show how the offending text could be modified. ${ }^{72}$ Smyth looks to have complied, insofar as Woolf's name does not appear in the published version. Conversely, Woolf initially seemed to concede the point in her speech to the London/National Society for Women's Service. Woolf admits that the story of how she became a successful author of literature was "very tame" compared with that of Smyth in music. ${ }^{73}$ As her own history unfolds over the course of the speech, however, it becomes clear that the pursuit of her own career was not as untroubled as her words at first suggest, and her ironic claims of tameness merely serve to reinforce the harsh reality of the plight of the professional woman in the Edwardian era.

This disparity between the perspectives articulated by the two women was surely the result of their distinct disciplinary positions. It was most telling when both drew upon the same piece of evidence to illustrate different points. In A Room of One's Own, Woolf recounted the tale of Jane Austen's hiding her manuscripts so that her visitors would not see her work; the anecdote was provided as evidence of the extreme measures that one nineteenth-century woman was compelled to take in order to write a novel, given the need for discretion even within the supposed sanctity of her own home. ${ }^{74}$ When Smyth alluded to the same story in "A Final 
Burning of Boats” (which had been published in the year prior to A Room of One's Own), it was to demonstrate that "On certain fields the battle is won" $:{ }^{75}$ she sought to show that it was at least possible for a woman to become a published novelist at a time during which she could not have been, say, a composer. Smyth’s words resonate strongly with those of Woolf in the extract from Three Guineas quoted above, in which she discussed the absence from literature of the sexoriented "battles" found in other disciplines; and it was by no means the only juncture at which the two writers seemed independently to be advancing opinions that, though serving different purposes, ran very much along the same lines.

One of the clearest examples of this congruity has its origins in A Room of One's Own, in which Woolf stated, with reference to Coleridge's renowned view of the androgyny of the "great mind": ${ }^{76}$

it is natural for the sexes to co-operate. ... The normal and comfortable state of being is that when the two live in harmony together, spiritually co-operating. If one is a man, still the woman part of the brain must have effect; and a woman also must have intercourse with the man in her. . . It is fatal to be a man or woman pure and simple; one must be woman-manly or man-womanly. ${ }^{77}$

A Room of One's Own had indirectly precipitated Smyth's initial meeting with Woolf, having interested her sufficiently to lead her to seek out its author. Given her engagement with the volume, it is hardly unexpected that Smyth was to write in an analogous manner just a few years later in "Female Pipings in Eden”: “Art is bi-sexual, the female element implicit with the male.”78 Where Woolf's subject had been the writer's necessity to draw on elements of the 
opposing sex, Smyth’s observation touched upon the continuing exclusion of women from certain professional orchestras and the fresh perspectives that their admission within others had brought to music performance. Nonetheless, both women held that the ideal state for art would be one that combined both male and female aspects, and that the presence of women-whether creating original works or providing new interpretations of existing art—enriched their respective disciplines. Smyth made the link between the two fields explicit; elsewhere in the same essay she wrote: "Few deny that the Brontës and Jane Austen brought a new note into our literature. Why then should not our musical contribution be equally individual and pregnant?’79 However, whereas Woolf had written in A Room of One's Own that "a woman writing thinks back through her mothers, ${ }^{, 80}$ Smyth elected not to follow her friend's example. Woolf repeatedly paid tribute to literary women in history, including Aphra Behn, Fanny Burney, Jane Austen, the Brontës, and George Eliot, but, as discussed above, Smyth was disconcertingly quiet about her female precursors. As Woolf noted, history offered no traditions of women in music that were truly comparable to those in literature; ${ }^{81}$ at the same time, Smyth eschewed some valuable opportunities to raise public awareness of those women composers who had achieved recognition. Even her earliest biographer, Christopher St John, conceded, "It is a mistake . . . to assume that there never had been any women composers before Ethel Smyth." ${ }^{82}$ As her memoirs attest, Smyth knew of Fanny Mendelssohn, Josephine Lang, Clara Schumann, and Augusta Holmès, to which list we might add Germaine Tailleferre, if only on the basis of Smyth's reading of A Room of One's Own. It seems highly likely that she had also encountered the music of Louise Reichardt (1779-1826) during her time in Germany, as Reichardt’s songs, which had been published in the early decades of the 1800s, retained their popularity throughout the century. 
Moreover, Smyth could not have avoided taking notice—perhaps even with envy—of the successful women composers active in Britain during her lifetime, including Maude Valérie White (1855-1937) and Liza Lehmann (1862-1918). ${ }^{83}$ Through her early involvement with the Society of Women Musicians, which was founded in 1911, Smyth must have encountered both Lehmann (its inaugural president) and White, together with other acclaimed female composers such as Cécile Chaminade (1857-1944) and Rebecca Clarke (1886-1979). ${ }^{84}$ White’s autobiographical writings include a story of Smyth visiting her cottage at Taormina, presumably in 1903 during the tour of Sicily recounted in What Happened Next. ${ }^{85}$ Smyth, conversely, omitted any reference to White's hospitality. Elsewhere, Smyth had crossed paths with another contemporary, Adela Maddison (1866-1929), whose orchestral Irische Ballade (1909, now lost) she offered to convey to the composer Frederick Delius with the aim of securing its performance. $^{86}$

Notwithstanding the manifold unchronicled encounters that Smyth must have had with other women composers and their music over the course of her long and busy career, a number of noteworthy connections can be easily drawn between her and some of the very same figures she neglected to mention in her prose. As evidence, Smyth’s discussion of exclusions in the third edition of Grove's Dictionary of Music and Musicians once again becomes relevant here. Most of the women composers cited in the previous paragraphs were included in this edition of the monumental dictionary, though many were given short shrift. Maddison, however, continued to be omitted, and since Smyth had helped to promote her on at least one previous occasion, it is curious that Smyth did not seek to put forward her case in this instance too; perhaps she felt more sufficiently distanced from Dorothy Howell, who was some two generations younger. ${ }^{87}$ Whatever the reason, rather than recognize and promote her rivals in her literature, Smyth wrote 
self-serving polemics on the plight of the woman composer that were mere adjuncts to her autobiographies. In lieu of citing contemporaries, Smyth provided an extraordinary “origin myth" for women in music, reaching back to the origins of Woman herself according to biblical legend. The Garden of Eden story that frames Smyth's most fiercely feminist essay, and from which she derived its title, ${ }^{88}$ is on the face of it chillingly simple: when Eve first took a reed to her lips and started to play, Adam's reaction was hostile to say the least. In Smyth's tale, music thereafter became an overwhelmingly male-dominated domain, in which women were silenced and from which they were excluded at every opportunity and by every means available. ${ }^{89}$

Jane Marcus has observed that "Female Pipings in Eden does for women in music what Virginia Woolf did for women in literature; it gives women artists a myth of their own creative origins and urges them to struggle for possession of the past in order to forge the future." ${ }^{90}$ If Smyth's feminist writings can be regarded as musical counterparts to Woolf's own, then the nature of the general relationship between them, in terms of the scope of their coverage, also warrants further exploration. Although Smyth alluded to topics as diverse as literature, the visual arts, politics, and even science in the course of her tirades, her attentions were always focused narrowly on the field of music, usually on herself and her experiences as a composer. One passage of "Female Pipings in Eden" unabashedly proclaimed her self-referential approach:

If you have reached a mature age, and are still more or less in possession of your faculties, people have had time to find you out, and will know whether or no[t] a study like this is born of lack of balance, non-perception of the other side of a question, disregard for truth, ill temper, inflamed egotism, or vindictiveness ... One hopes to be acquitted of these things, but Lord! what does it matter? ${ }^{91}$ 
By contrast, Woolf endeavored to incorporate discussion of women's situation in more general terms across the social, political, and professional spectrums rather than to concentrate on her own sphere of activity. Woolf's diversity meant that her broad and humane connections between various other disciplines precluded the focus evinced by Smyth. To use the terms set forth by Isaiah Berlin, Woolf was a fox, knowing many things, whereas Smyth (for all her multifarious activities) was a hedgehog who knew one big thing: herself. ${ }^{92}$ Woolf seemed to acknowledge that music was Smyth's field, and that the composer should be the one to write about it. Toward the end of her life, she suggested that Smyth write a "Common Reader review of music,"93 presumably one fashioned after her own literary example. ${ }^{94}$ Ten years earlier, having read Smyth’s short article "Composers and Critics," ${ }^{95}$ Woolf had written, "What I should like would be, in another article, a purely objective statement of the exact disabilities (not being allowed to play in orchestras etc which women suffer in music.). ${ }^{\text {"96 }}$ Without her deference to Smyth on musical topics, Woolf might have undertaken this task herself; as we shall see momentarily, she briefly considered doing so. But Woolf was aware that music was not her area of expertise. In a different context she once remarked to Smyth, "As well [to] ask a deaf donkey to criticise Mozart."97

Woolf did indeed shy away from detailed consideration of music per se in her feminist literature. However, her reticence was not simply due to her perception that there was little she could usefully add to Smyth's previously published critiques, or to her having little desire to expand into her touchy friend's territory. In the course of writing Three Guineas, Woolf sent Smyth a request for information on the opportunities denied to women in music: 
Information wanted: Are women allowed to play in orchestras? When was this, allowed, if so: and are they now musically, (as far as training goes) equal with the other sex? I've now got to produce, in the usual fury and despair and haste, what should have been a booklet, and has swollen to a book, in which this fact, or fiction, occurs, and I want it to be accurate, but have lost my note, so appeal to you. ${ }^{98}$

Though Smyth did not address these questions exhaustively in "Female Pipings in Eden,” Woolf would nonetheless have found there many answers to her queries. Smyth discussed at some length the musical training and orchestral opportunities available to women, notably that some of the major orchestras had tentatively opened their doors to female players (around the time of the First World War), but many had since endeavored to exclude them again. ${ }^{99}$ It is even conceivable that the lost note to which Woolf referred in her letter had been taken from "Female Pipings in Eden,” which had recently fascinated her. ${ }^{100}$ Otherwise, it seems curious that Woolf waited so long to initiate this discussion, given that Smyth was the obvious person for her to approach.

Whatever the reason for this eleventh-hour solicitation of information, and whether or not a reply was forthcoming from Smyth, ${ }^{101}$ Woolf ultimately included in Three Guineas few notable references to music. The first occurs toward the end of the opening chapter, in a passage contending that the only real profession available to the "educated man’s daughter" (to use Woolf's frequently repeated formulation) was marriage itself:

It was with a view to marriage that [a woman's] mind was taught. It was with a view to marriage that she tinkled on the piano, but was not allowed to join an 
orchestra; sketched innocent domestic scenes, but was not allowed to study from the nude; read this book, but was not allowed to read that, charmed, and talked. ${ }^{102}$

Two further allusions to music, both found in Woolf's concluding third chapter, are also worthy of mention. One has already been quoted; the other occurs in the course of discussing the activities that nineteenth-century daughters might have pursued were it not for their fathers preventing them from doing so: "Some wanted to learn music, not to tinkle domestic airs, but to compose—operas, symphonies, quartets. Others wanted to paint, not ivy-clad cottages, but naked bodies." ${ }^{103}$ These three passages may clearly be read as echoes of one another, not least because they all place the practice of forbidding women from painting the nude side by side with that of prohibiting them from joining orchestras; ${ }^{104}$ in one passage, they are presented as being general policies of schools of art and music respectively. Woolf's consistent grouping of music with other disciplines, particularly the visual arts, suggests a reluctance to consider this field purely on its own. This pattern is confirmed by several additional passing references to music in Three Guineas that are too inconsequential to warrant specific examination here. ${ }^{105}$ Another of Woolf's recurring themes is that the one form of music-making that was socially acceptable for a woman was that of desultory domestic piano-playing. The image invites comparison with the character Rachel Vinrace, the music-loving protagonist of Woolf's first published novel, The Voyage Out, who had attained a high standard on the instrument by early adulthood. ${ }^{106}$ At one point in Three Guineas, the pastime is explicitly identified as a way of entrancing marriage prospects, for a woman who was seen as an "accomplished" pianist could indeed attract suitors with her fetching talent; as William Weber has noted, to be presented in salon performance with the aim of obtaining a spouse was a common practice in the nineteenth century. ${ }^{107}$ 
What, exactly, lay in Woolf's mind as she wrote these passages about music in Three Guineas? Rachel Vinrace aside, the picture that Woolf painted of the unmarried woman idly tinkling on a cottage piano doubtless had its origins in the novels of Jane Austen that she so adored, ${ }^{108}$ with their plethora of heroines for whom-like the author herself-the instrument was an important part of their lives: Marianne Dashwood in Sense and Sensibility; Elizabeth and Mary Bennet in Pride and Prejudice; Jane Fairfax and Emma Woodhouse in Emma; Anne Elliot in Persuasion. ${ }^{109}$ Reading between the lines, however, the figure who emerges most strongly from the discussions of music in Three Guineas is Smyth herself. Whereas "Female Pipings in Eden" had previously indicated that the issue of women's exclusion from orchestras was rather more complex than Woolf's treatment suggested, Smyth's essay nonetheless appears to have exerted significant influence on her friend. The emphasis that Woolf placed on the orchestral scene, and on the formal training available to women in conservatories (as against, for instance, exploring the current status of women as singers, music teachers, or composers), bears traces of having absorbed the very elements around which Smyth's discussion had crystalized in “Female Pipings in Eden,” especially the second chapter, “Women’s Training Hitherto.”110 Moreover, Smyth had quite literally overcome the opposition of her father, an upper middle-class army general, in order to have a career in music at all. Her memoirs relate that there had never been great sympathy between them. ${ }^{111}$ He reportedly considered his young daughter's ideas of studying music in Leipzig to be nonsensical; he despised her early harmony tutor, Alexander Ewing, for his role in educating her. In consequence, the daughter became increasingly disobedient, secretly borrowing money and traveling to London unchaperoned to attend concerts. Her behavior became so ungovernable that she and her father soon clashed on a daily basis: she refused to attend church; she declined to sing at family dinner parties; and she even completely 
stopped speaking to people. Ultimately, her father had no option but to consent reluctantly to his daughter’s plans.

Woolf would also have appreciated that Smyth determinedly pursued a professional career in music rather than marriage. Quite aside from the issue of her sexuality, Smyth indicated that the nature of her artistic activities ruled out matrimony. In Impressions that Remained, she wrote pointedly, "Where should be found the man whose existence could blend with mine without loss of quality on either side? . . . My work must, and would always, be the first consideration." ${ }^{112}$ Most importantly, in Woolf’s eyes, Smyth was that pioneering woman who strove to compose operas, symphonies, and quartets, rather than consign herself to the lighthearted piano airs that contemporary society deemed to be appropriate for women. Although Smyth never saw to completion her early sortie into the realm of the symphony (unless The Prison, from its subtitle, is to be regarded as such), she did write several string quartets, in addition to the six magnum opuses whose existence led Woolf to refer to her as "the first woman to write an opera.” If Woolf's words are no more than the result of lack of historical knowledge or an authorial slip, then Smyth’s self-centeredness would go far to account for it. But if those words are to be interpreted along the lines proposed earlier in this essay, then there is clearly a further reason why Woolf held that Smyth's operas represented genuine “women’s work” in the way that her autobiographies did not. By resisting the strictures of the patriarchal music establishment as well as the crushing burden of history, Smyth may have made an authentic and focused contribution to the self-representation of women through her operas that was far more powerful than the diffuse narcissism of her literary writings.

Within this context, Woolf's statement that “there's never been a woman[']s autobiography” must be examined in greater detail. Woolf's use of the term “autobiography” 
implies that she did not view anything in her own output as such, to say nothing of many broadly analogous writings by a wide range of other female authors. Given that modern critics have turned to documents such as correspondence, diaries, autobiographical fragments, and fictional discourses as faithful records of women's self-narration, ${ }^{113}$ Woolf seems to have unwittingly adopted a disconcertingly patriarchal view by discounting these sources in favor of fully fledged published autobiographies, such as Cardinal Newman's seven-part Apologia pro vita sua. ${ }^{114}$ She even remarked upon the absence of a female counterpart to Rousseau, whose Confessions is commonly considered to be the "father" of modern autobiography. ${ }^{115}$ Yet she was aware that by writing a letter, the author gave "back a reflection of the other person." 116 Surely, the document discussed here is no exception. Given my arguments that Woolf held Smyth's texts to have been written according to masculine autobiographical paradigms, as epitomized by her jarring egotism and especially her persistent recourse to the bruising, patriarchal "I," it is no surprise that Woolf's objections to these practices are particularly pronounced in the case of "Female Pipings in Eden,” in which Smyth's voice is heard at its most strident. Woolf commented upon an early draft of this polemic that

as you will guess what I criticise is what you say to be necessary—-that is the autobiography. I hate it. I dont think it adds any thing to what you have said. I think the personal details immensely diminish the power of the rest. Because one feels_-but I wont go on; for I am aware that I may be prejudiced. I hate any writer to talk about himself. ... I I hate personal snippets more and more. And the mention of "I" is so potent—such a drug, such a deep violet stain—-that one in a page is enough to colour a chapter.... 
... give all the facts and all the dates; the more the better; but let them be about other people, not E[thel] S[myth]. My own longing in reading your article is to escape the individual; and to be told simply, plainly, objectively.... You will say Oh but I must cite my case because there is no other. But my dear Ethel your case is that there are a thousand others. Leave your own case out of it; theirs will be far far stronger. Enough, I only say this because—well, I didnt write “A room” [i.e. A Room of One's Own] without considerable feeling even you will admit; I'm not cool on the subject. And I forced myself to keep my own figure fictitious; legendary. If I had said, Look here am I uneducated, because my brothers used all the family funds which is the fact—-Well theyd have said; she has an axe to grind; and no one would have taken me seriously ... ${ }^{117}$

The genre of unashamed first-person autobiography was clearly anathema to Woolf, but it was nevertheless one into which she had ventured and failed. Her deeply personal memoir "A Sketch of the Past" - which, significantly, included some intimate details about her own sexual history — was abandoned in November 1940, just one month prior to writing the letter quoted in the epigraph of this essay. ${ }^{118}$ Could Woolf's inability to come to terms with the genre of the memoir provide an explanation why she continued to encourage Smyth’s idiosyncratic brand of literature, even as she castigated its egocentricity and inferior writing? Did she recognize that Smyth, for all her literary flaws, was nevertheless capable of producing an androgynous text that, though it adhered to the patriarchal model of conventional autobiography, remained stubbornly faithful to the author's gender? Was the purpose of that letter, written on the eve of what was to be her final Christmas, an invitation to her friend to take up the challenge where she had left off? 
If so, were her words "I leave it to you" in reference to more than the effects of the cold winter morning on her pen?

Writing of the dynamic interaction between these two extraordinary artists, Hermione Lee has remarked, “Ethel’s monomania and narcissism felt to Virginia like a grotesque parody of her own self-absorption." ${ }^{119}$ It is deeply ironic, for instance, that Woolf used A Room of One's Own to explain to Smyth why "Female Pipings in Eden" should not merely recount the author's own case- thereby drawing on the example of herself while simultaneously counseling Smyth to refrain from this same practice. In view of the considerable synergy between the opinions advanced by the two writers, it may have become apparent to Woolf that the self-centered Smyth was too similar to her for comfort. For Woolf, the safest course was to skate quickly over musical subjects, for otherwise Smyth's egotism might have been too readily recognizable in her own feminist critiques. On the other hand, Smyth did not concern herself with such scruples. As indicated earlier in this essay, she referred to her literary activity as "a second string whereon to play, as well as one can, the tune life is always making up in one’s heart." ${ }^{120}$ It would seem, however, that Woolf's evasion of music — the very area that was the focus of Smyth's life and prose - might have served a wider purpose than merely allowing her friend the space to play that particular tune unaccompanied.

\section{Notes}


Christopher Wiley is Senior Lecturer in Music and Director of Undergraduate Studies at City University London, UK. He is the author of articles appearing in Music and Letters, Comparative Criticism, Biography, and Journal for Eighteenth-Century Studies, as well as book chapters on subjects as wide-ranging as Haydn, Michael Jackson, and Buffy the Vampire Slayer. His doctoral dissertation, Re-writing Composers’ Lives: Critical Historiography and Musical Biography, undertaken at the University of London, provides a critical examination of musical biography through comparative studies of texts on several canonical composers. He is currently preparing a monograph on the earliest volumes of the celebrated “Master Musicians” series (1899-1906). Other research interests include music and gender studies, popular music studies, and music for television.

This essay originated in a paper delivered at The Fourteenth Annual International Conference on Virginia Woolf, “Back to Bloomsbury,” Institute of English Studies, University of London, UK, 24 June 2004, which in turn developed from an earlier study of Ethel Smyth and Virginia Woolf (see note 9 below). I wish to thank Irene Zedlacher and the editors and anonymous readers at The Musical Quarterly for their generous and insightful input.

1 Virginia Woolf to Ethel Smyth, 24 December 1940, in The Letters of Virginia Woolf, ed. Nigel Nicolson and Joanne Trautmann, 6 vols. (London: Hogarth, 1975-80) [henceforth Letters], 6:453. In referencing personal documents, I follow the dating suggested by the editors (though rendering the dates themselves in a standardized form) and, when quoting, I adhere to the spelling and punctuation of the original. 
2 A comprehensive list of Smyth's works, compiled by Jory Bennett, is found in The Memoirs of Ethel Smyth, ed. Ronald Crichton (Harmondsworth, Middlesex: Viking, 1987), 373-81.

3 Elizabeth Wood has recently provided a detailed analytical account of Smyth's deafness, its onset, and its implications for her later compositional career, in her article “On Deafness and Musical Creativity: The Case of Ethel Smyth,” Musical Quarterly 92, nos. 1-2 (SpringSummer 2009): 33-69.

4 Ethel Smyth, What Happened Next (London: Longmans, 1940), 2. Elsewhere in her literary texts, Smyth had similarly developed the metaphor of her music and her writing being, respectively, her first and second "strings."

5 Virginia Woolf, The Common Reader: First Series (London: Hogarth, 1925); A Room of One’s Own (London: Hogarth, 1929). For the record, Woolf's novels (all published by Hogarth Press of London, which she owned jointly with her husband Leonard, unless otherwise stated) are as follows: The Voyage Out (London: Duckworth, 1915), Night and Day (London: Duckworth, 1919), Jacob’s Room (1922), Mrs Dalloway (1925), To the Lighthouse (1927), Orlando: A Biography (1928), The Waves (1931), The Years (1937), and Between the Acts (1941); her other major publications include Flush: A Biography (1933), Three Guineas (1938), and Roger Fry: A Biography (1940).

6 See, for instance, Linda Anderson’s discussion in “Virginia Woolf: 'In the Shadow of the Letter “I,"," in her Women and Autobiography in the Twentieth Century: Remembered Futures (Hemel Hempstead: Prentice Hall/Harvester Wheatsheaf, 1997), 42-75, at 46-47. 7 See Woolf to Smyth, 9 July 1940, in Letters, 6:403-04. 
Smyth's four volumes of chronological autobiography, which recount the first fifty years of her life, are Impressions that Remained: Memoirs, 2 vols. (London: Longmans, 1919); As Time Went On... (London: Longmans, 1936); and What Happened Next; a further volume, A Fresh Start, was unfinished at her death in 1944. Her other book publications are: Streaks of Life (London: Longmans, 1921, 2/1924); A Three-Legged Tour in Greece (London: Heinemann, 1927); A Final Burning of Boats etc. (London: Longmans, 1928); Female Pipings in Eden ([London]: Peter Davies, 1933, 2/1934); Beecham and Pharaoh (London: Chapman \& Hall, 1935); Inordinate (?) Affection: A Story for Dog Lovers (London: Cresset, 1936); and Maurice Baring (London: Heinemann, 1938).

9 For a more comprehensive explanation of some of the arguments summarized in the next two paragraphs, see Christopher Wiley, “'When a woman speaks the truth about her body’: Ethel Smyth, Virginia Woolf, and the Challenges of Lesbian Auto/biography,” Music and Letters 85, no. 3 (August 2004): 388-414; inevitably, in expanding its themes, a small amount of material drawn from this earlier article is reworked in the present essay.

10 See Woolf, A Room of One's Own, 150.

11 Suzanne Raitt, ““'The tide of Ethel’: Femininity as Narrative in the Friendship of Ethel Smyth and Virginia Woolf,” Critical Quarterly 30, no. 4 (Winter 1988): 3-21, at 14.

12 Like many lesbian-identified women, Smyth’s sexuality was complex, not least owing to her long-standing relationship with the writer and philosopher Henry Brewster, which has recently been subjected to renewed scholarly scrutiny by Amanda Harris in "The SmythBrewster Correspondence: A Fresh Look at the Hidden Romantic World of Ethel Smyth,” 
Women \& Music: A Journal of Gender and Culture 14 (2010): 72-94. Nonetheless, I follow the lead of a range of modern lesbian theory in considering that this in no way compromises Smyth's being located within the broad spectrum of female homosexuality that Adrienne Rich famously termed the "lesbian continuum.” Rich, “Compulsory Heterosexuality and Lesbian Existence,” Signs: Journal of Women in Culture and Society 5, no. 4 (1980): 631-60, repr. in her Blood, Bread and Poetry: Selected Prose 1979-1985 (New York: W.W. Norton, 1986), 23-75.

13 Smyth's six operas are Fantasio (1892-94), Der Wald [The Forest] (1899-1901), Les naufrageurs [The Wreckers; Standrecht] (1902-04), The Boatswain's Mate (1913-14), Fête galante (1921-22), and Entente cordiale (1923-24).

14 This is the interpretation I put forward in "'When a woman speaks the truth about her body,"” 401-02, 409-12.

15 Two frequently cited instances of sexual rhetoric in discourse on Smyth’s works (specifically, indicating that the nature of her music is somehow unexpected from a woman composer) are George Bernard Shaw's review of a performance of Smyth’s Overture to Shakespeare's Antony and Cleopatra in 1892, and John Fuller Maitland's discussion of Smyth's Mass in D in the second edition of Grove's Dictionary, which was reproduced almost verbatim in the following three editions. [George] Bernard Shaw, Music in London 1890-94, 3 vols. (London: Constable, 1932), 2:36-40, at 37 (originally published in The World, 2 March 1892); [J.A. Fuller] M[aitland], “Smyth, Ethel Mary,” in Grove’s Dictionary of Music and Musicians, ed. J.A. Fuller Maitland, 2nd ed., 5 vols. (London: Macmillan, 1904-10), 4 
(1908): 490-91, at 490. That Smyth was indeed aware of, and objected to, the gendered remarks occasioned by her music is evident from her subsequent correspondence with Shaw; see Smyth, “A Final Burning of Boats,” A Final Burning of Boats etc., 3-54, at 34-36. See in particular Elizabeth Wood, "Performing Rights: A Sonography of Women’s Suffrage," Musical Quarterly 79, no. 4 (Winter 1995): 606-43, in which a variety of musical codifications of lesbianism (and feminist tendencies) are identified in relation to Smyth's works associated with the period she devoted to the women's suffrage movement between 1910 and 1912. Other of Wood's enlightening articles in which similar lines of inquiry are pursued include “Gender and Genre in Ethel Smyth’s Operas,” in The Musical Woman: An International Perspective, vol. 2, ed. Judith Lang Zaimont, Catherine Overhauser, and Jane Gottlieb (Westport, CT: Greenwood, 1987), 493-507; “Lesbian Fugue: Ethel Smyth’s Contrapuntal Arts," in Musicology and Difference: Gender and Sexuality in Music Scholarship, ed. Ruth A. Solie (Berkeley: University of California Press, 1993), 164-83; "Sapphonics," in Queering the Pitch: The New Gay and Lesbian Musicology, ed. Philip Brett, Elizabeth Wood, and Gary C. Thomas (New York: Routledge, 1994), 27-66, at 44-55; and “The Lesbian in the Opera: Desire Unmasked in Smyth's Fantasio and Fête galante," in En travesti: Women, Gender Subversion, Opera, ed. Corinne E. Blackmer and Patricia Juliana Smith (New York: Columbia University Press, 1995), 285-305. For further discussion, see Wiley, “'When a woman speaks the truth about her body,” 410-11.

17 Among several other studies see, for example, Peter Jacobs, ““The Second Violin Tuning in the Ante-room': Virginia Woolf and Music,” in The Multiple Muses of Virginia Woolf, ed. 
Diane F. Gillespie (Columbia: University of Missouri Press, 1993), 227-60; Patricia Laurence, “The Facts and Fugue of War: From Three Guineas to Between the Acts,” in Virginia Woolf and War: Fiction, Reality, and Myth, ed. Mark Hussey (Syracuse, NY: Syracuse University Press, 1991), 225-45; Émilie Crapoulet, Virginia Woolf: A Musical Life (London: Cecil Woolf, 2009); and Emma Sutton, Virginia Woolf and Classical Music: Politics, Aesthetics, Form (Edinburgh: Edinburgh University Press, 2013).

18 These include Jane Marcus, "Virginia Woolf and Her Violin: Mothering, Madness, and Music,” in Mothering the Mind: Twelve Studies of Writers and their Silent Partners, ed. Ruth Perry and Martine Watson Brownley (New York: Holmes and Meier, 1984), 180-201, repr. in Marcus, Virginia Woolf and the Languages of Patriarchy (Bloomington: Indiana University Press, 1987), 96-114; Raitt, “The tide of Ethel”; and Elicia Clements, "Virginia Woolf, Ethel Smyth, and Music: Listening as a Productive Mode of Social Interaction,” College Literature 32, no. 3 (July 2005): 51-71. There are also a number of biographical texts on one of the women that feature a dedicated chapter on the other.

19 For instance, Elicia Clements has asserted that “Smyth did not influence Woolf’s musical thinking directly,” a view I hope to have nuanced in the course of this essay by adding wider context. Clements, “Virginia Woolf, Ethel Smyth, and Music,” 51. Virginia Woolf, “Ethel Smyth,” The New Statesman, 23 April 1921, repr. in The Essays of Virginia Woolf, ed. Andrew McNeillie, 4 vols. (London: Hogarth, 1986-94; vols. 5-6, ed. Stuart N. Clarke, 2009-11), 3:297-301.

21 Woolf to Lytton Strachey, 30 November 1919, in Letters, 2:405. 
22 See Woolf's letters to Smyth of 11 February 1930 (Letters, 4:136); 1 April 1932 (Letters, 5:40); and 11 and 13 May 1936 (Letters, 6:39).

23 See Woolf's letters to Smyth of 7 September 1932 (Letters, 5:101); 21 October 1932 (Letters, 5:112); 27 and 29 August 1934 (Letters, 5:326); 11 and 13 May 1936 (Letters, 6:39); and 9 July 1940 (Letters, 6:404). See Woolf's letters to Smyth of 12 March 1936 (Letters, 6:21); 20 April 1936 (Letters, 6:27); 17 September 1938 (Letters, 6:272); and 9 January 1939 (Letters, 6:309). Presumably, Woolf had in mind Smyth’s next volume of memoirs, What Happened Next. Woolf to Smyth, 14 April 1939, in Letters, 6:326.

26 The editors of The Letters of Virginia Woolf, Nicolson and Trautmann, suggest that Woolf “probably invent[ed] it as a collective title for all [Smyth’s] autobiographies” (Letters, 6:326n2). It is more likely that Woolf simply made a rather embarrassing mistake, given that the recipient of the letter was none other than Smyth herself. At first glance, it may appear that Woolf was endeavoring to reference Streaks of Life, though surely she would have known the title of that volume well enough by 1939. Another possibility is that Woolf was using a title that the composer had considered, but ultimately discarded prior to publication. 27 The letter starts "I've only ten minutes before driving off across the hill to lunch" and ends “This is a scribble, but write, and I will try to find a better mood soon.” Woolf to Smyth, 24 December 1940, in Letters, 6:453, 454. 
Virginia Woolf, diary entry, 28 November 1919, in The Diary of Virginia Woolf, ed. Anne Olivier Bell and Andrew McNeillie, 5 vols. (London: Hogarth, 1977-84) [henceforth Diary], 4 February 1931, 4:10. Woolf, diary entry, 16 June 1930 (Diary, 3:306).

30 See Smyth, "Brahms," chap. 24 of Impressions that Remained, 1:261-70, and "Recollections of Brahms,” Female Pipings in Eden, 57-70.

31 See Smyth, Impressions that Remained, 1:85.

32 See Jane A. Bernstein, “'Shout, Shout, Up with Your Song!’ Dame Ethel Smyth and the Changing Role of the British Woman Composer,” in Women Making Music: The Western Art Tradition, 1150-1950, ed. Jane Bowers and Judith Tick (Basingstoke: Macmillan, 1986), 304-24, at 309-10.

Donald Francis Tovey, “Ethel Smyth: Mass in D, for Chorus and Orchestra,” in Essays in Musical Analysis, 7 vols. (London: Oxford University Press, 1935-44), 5:235-42. Woolf knew Tovey during his long tenure as Reid Professor of Music at Edinburgh University; Smyth’s The Prison received its first performance at one of Tovey’s Edinburgh concerts, conducted by the composer, on 19 February 1931.

34 Kathleen A. Abromeit, “Ethel Smyth, 'The Wreckers,' and Sir Thomas Beecham,” Musical Quarterly 73, no. 2 (1989): 196-211, at 200.

35 Although the earliest surviving complete opera is Jacopo Peri’s Euridice (1600), to which Caccini himself contributed various numbers, Caccini hastily composed and published a setting of the entire opera such that his version appeared in print first. 

Musicology and Difference, ed. Solie, 281-304. The opera's plot is itself telling, in that the fate of the eponymous Ruggiero is entirely dependent upon the outcome of the conflict between the two sorceresses who wield the real power in the opera, Alcina (his captor) and Melissa (his liberator). More significant for this article is the matter of the musical setting. According to Cusick, Caccini's music constructs male and female characters (in particular, Ruggiero and Alcina) differently in terms both of melody and tonality, for instance, in the tendency to write in sharp keys for the former and flat keys for the latter. See Cusick, "Of Women, Music, and Power,” 290-301; see further her "Francesca Caccini,” in The New Grove Dictionary of Opera, ed. Stanley Sadie, 4 vols. (London: Macmillan, 1992), 1:669. While a note of caution should perhaps be raised with respect to such a reading of a work written during a period when little documented evidence exists for the mapping of binaries of gender onto those of tonality, the potential for the use of sharp and flat keys to underscore polar opposites such as male and female would surely not have been lost on composers of the time, especially since the prevalent tuning systems gave rise to distinct characteristics being identified with individual keys. On the subsequent recognition by writers on music of such characteristics and their implications to composers, see Rita Steblin, A History of Key Characteristics in the Eighteenth and Early Nineteenth Centuries, 2nd ed. (Rochester, NY: University of Rochester Press, 2002). Speaking in general terms, very little of the music of opera may be regarded as truly gender-neutral, since the vast majority of its passages are inextricably associated with one or more characters and hence with their sex. When 
considered alongside Smyth's output in the genre, one can only conclude that Caccini's $L a$ liberazione di Ruggiero provides, on the face of it, a broadly comparable instance of “women’s opera,” but one that antedates those of Smyth by nearly three centuries. Jacqueline Letzter and Robert Adelson, Women Writing Opera: Creativity and Controversy in the Age of the French Revolution (Berkeley: University of California Press, 2001). See The New Statesman, 2, 9, and 16 October 1920, for the article by MacCarthy that had prompted Woolf's initial letter, and their subsequent exchange; Woolf's discussion of Smyth is to be found in the 16 October edition. For further information, see "The Intellectual Status of Women,” Appendix III, Diary, 2:339-42, where Woolf's correspondence is reproduced.

39 Woolf, A Room of One's Own, 82-83. The internal quotation is from Cecil Gray, A Survey of Contemporary Music (London: Humphrey Milford for Oxford University Press, 1924), 24546. Gray's discussion of Tailleferre concludes in much the same vein: "Considered apart from her sex, her music is wholly negligible.” In fact, his text was first published four years earlier than the date cited by Woolf, though her point still stands.

40 See Jacobs, “The Second Violin Tuning in the Ante-room,” 231-32.

41 Virginia Woolf, “The Opera,” The Times, 24 April 1909, and “Impressions at Bayreuth,” The Times, 21 August 1909, both repr. in The Essays of Virginia Woolf, ed. McNeillie, 1:269-72 and 288-93, respectively.

42 See, for example, Jane Marcus, "Enchanted Organ, Magic Bells: Night and Day as a Comic Opera” and “The Years as Götterdämmerung, Greek Play, and Domestic Novel,” in her Virginia Woolf and the Languages of Patriarchy, 18-35 and 36-56, respectively; Emma 
Sutton, “'Within a Space of Tears': Music, Writing, and the Modern in Virginia Woolf's The Voyage Out," in Music and Literary Modernism: Critical Essays and Comparative Studies, ed. Robert P. McParland (Newcastle: Cambridge Scholars Publishing, 2006), 50-65. Grove's Dictionary of Music and Musicians, ed. H.C. Colles, 3rd ed., 5 vols. (London: Macmillan, 1927-28). Smyth would undoubtedly have had a special interest in the treatment of women composers in this publication given the gendered nature of discussion in her entry in the previous edition (see above, n15).

44 Indeed, Howell only ever attained the status of a minor composer. Though she had shown significant early promise-her symphonic poem Lamia was premiered at one of Henry Wood's celebrated Promenade Concerts in 1919 (she was aged just 21) — the expectations that she generated in musical circles in the 1920s were ultimately not sustained. Tellingly, she was added to the fourth edition of Grove's Dictionary (1940) but became one of a number of women composers omitted from the sixth (1980, edited by Stanley Sadie, as The New Grove Dictionary of Music and Musicians), which was published two years prior to her death. She was reintroduced in the seventh edition (2001), via The New Grove Dictionary of Women Composers, ed. Julie Anne Sadie and Rhian Samuel (London: Macmillan, 1994). 45 Smyth, “A Final Burning of Boats,” 49.

46 See, for instance, Smyth, Impressions that Remained, 2:35-37, 73-75, and 84-87. 47 Smyth to her mother, April 1878, quoted in Smyth, Impressions that Remained, 1:236-37. 48 A rare reference to the compositional activity of Elisabeth (Lisl) von Herzogenberg, one of the most influential characters in Smyth’s entire life, similarly occurs in a passage of 
reproduced correspondence. Smyth wrote: "She is absurdly musical and though she doesn't compose much (only songs), is the first feminine musical genius (bar Frau Schumann) that I have met.” Smyth to her mother, 7 April 1878, quoted in Smyth, Impressions that Remained, $1: 237$.

49 Specifically, the three songs of Clara Schumann's op. 12 were combined with nine by her husband Robert and jointly published as his op. 37, Zwölf Gedichte aus F. Rückert’s “Liebesfrühling” (Leipzig, 1841); six of Fanny Mendelssohn’s songs were published under her brother Felix’s name, three each in his Zwölf Gesänge, op. 8 (Berlin, 1826-27) and Zwölf Lieder, op. 9 (Berlin, 1830). However, both of these women composers had also published works on their own, the bulk of Clara Schumann's output being issued separately.

50 Smyth, “Augusta Holmès, Pioneer” [July 1921], A Final Burning of Boats etc., 126-36, and What Happened Next, 156-57. Holmès’s “Home Rule” song, which Smyth was fond of performing, is also discussed in As Time Went On..., 129-30; her symphonic poem Irlande is mentioned, in connection with Henry Wood, in A Final Burning of Boats etc., 80.

51 Holmès’s four operas—Héro et Léandre, Astarté, Lancelot du lac, and La montagne noirewere composed between 1875 and 1884 .

52 Smyth, What Happened Next, 157.

53 Smyth, What Happened Next, 156.

54 Smyth, “Augusta Holmès, Pioneer,” 131.

55 Smyth, “Augusta Holmès, Pioneer,” 131.

56 See Woolf to Smyth, 15 September 1930, in Letters, 4:213. 
Smyth, “Augusta Holmès, Pioneer,” 133, 134.

Jann Pasler has argued that the early reception of Holmès’s music was linked to gender in terms of its supposed masculine characteristics; see the chapter "The Ironies of Gender, or Virility and Politics in the Music of Augusta Holmès,” in her Writing Through Music: Essays on Music, Culture, and Politics (Oxford: Oxford University Press, 2008), 213-48. Smyth, What Happened Next, 157. Smyth may have been suspicious of Holmès because she was known to have had a scandalous - yet obviously heterosexual—private life, given the string of love affairs that characterized her early adulthood (possibly including one with her composition teacher, César Franck) and her long association with the poet Catulle Mendès (with whom she had five children, but never married), as well as the general level of attention she was said to have received from men.

61 Smyth, “Female Pipings in Eden,” Female Pipings in Eden, 45, emphasis added.

62 Smyth, “Female Pipings in Eden,” 33.

63 Virginia Woolf, “Speech Before the London/National Society for Women’s Service, January 21 1931,” in The Pargiters by Virginia Woolf: The Novel-Essay Portion of The Years, ed. Mitchell A. Leaska (London: Hogarth, 1978), xxvii-xliv, at xxvii-xxviii. Earlier drafts of the start of the speech are even more strongly worded in this respect (see ibid., xxvii and 165).

64 Virginia Woolf, Three Guineas (London: Hogarth, 1938), 162, 163. Woolf’s observation about women's exclusion from orchestral playing was potentially misleading in that it did not acknowledge the possibilities that existed by the time of writing for women to join orchestras. 
Lady Radnor's all-female orchestra had been celebrated in England at the turn of the twentieth century, and a number of professional women's orchestras were founded in the 1920s and 1930s on both sides of the Atlantic. In particular, the British Women’s Symphony Orchestra had previously come to Woolf's attention, in that Smyth praised the ensemble in her essay "Female Pipings in Eden," 49.

65 Smyth, "Literary and Musical Careers Contrasted," chap. 3 of "Female Pipings in Eden,” 1418. See also “A Final Burning of Boats,” esp. 7-11.

66 See Wiley, “'When a woman speaks the truth about her body,” 413.

67 Smyth, "Female Pipings in Eden," 14. The two later quotations in this paragraph are taken from pages 15 and 16, respectively, of the same source.

68 Ethel Smyth, "Where Musical Criticism Goes Astray,” Female Pipings in Eden, 71-86.

69 Smyth, "Where Musical Criticism Goes Astray," 79.

70 Elicia Clements has recently argued the latter point with specific reference to A Room of One's Own and Female Pipings in Eden. Clements, “'As Springy as a Racehorse’: Female Piping in Eden as Rejoinder to Virginia Woolf's A Room of One's Own,” in Felsensprengerin, Brückenbauerin, Wegbereiterin: Die Komponistin Ethel Smyth / Rock Blaster, Bridge Builder, Road Paver: The Composer Ethel Smyth, ed. Cornelia Bartsch, Rebecca Grotjahn, and Melanie Unseld (Munich: Allitera Verlag, 2010), 55-68. My essay adds further context to this suggestion by demonstrating that the reciprocal influence between the two women's writings extended much further than these two texts alone, and by no means traveled in a single direction (from Woolf to Smyth) exclusively. 
71 Jane Marcus has speculated that the fourth chapter of Smyth’s “Female Pipings in Eden” must have formed at least part of her speech delivered to the London/National Society for Women's Service because it includes the story of the Woking Golf Course mentioned in Vera Brittain's oft-cited report on the event (quoted in Woolf, “Speech Before the London/National Society for Women’s Service, January 21 1931,” xxxiv-xxxv, unnumb. fn.). Marcus, “Thinking Back through Our Mothers,” in New Feminist Essays on Virginia Woolf, ed. Marcus (London: Macmillan, 1981), 1-30, at 22. Though the suggestion is not in itself inconceivable, the tale recounted in "Female Pipings in Eden" is not the one to which Brittain alluded, but a separate incident concerning the Golf Course at Cromer (19-20); the Woking anecdote is instead to be found in Smyth’s “A Final Burning of Boats,” 39-40, which had been published several years prior to her speech. Despite an offer from Woolf on behalf of Hogarth Press, Smyth’s speech was never published verbatim, and consequently has not survived. See Woolf to Smyth, 6 June 1933, in Letters, 5:192.

73 Woolf, “Speech Before the London/National Society for Women’s Service, January 21 1931,” xxix.

74 See Woolf, A Room of One's Own, 100-102.

75 Smyth, “A Final Burning of Boats,” 7. Despite her claim that Austen wrote her books “in secret," Smyth would have been aware (as would Woolf) that Austen's literary activity was known to her family and friends. Elsewhere, Smyth related that her great-uncle and Austen had been "close friends," and that Austen had surreptitiously attempted to find out his true 
feelings about one of her novels via a mutual acquaintance. See Smyth, Impressions that Remained, 1:5.

76 "The truth is, a great mind must be androgynous" (1 September 1832). Specimens of the Table Talk of the Late Samuel Taylor Coleridge, [ed. Henry Nelson Coleridge], 2 vols. (London: Murray, 1835), 2:96.

77 Woolf, A Room of One's Own, 147-48, 157.

78 Smyth, "Female Pipings in Eden," 47.

79 Smyth, "Female Pipings in Eden," 9-10.

80 Woolf, A Room of One's Own, 146.

81 Of the substantial body of scholarly work undertaken in recent years on the feminist deconstruction of music history and the corresponding recovery of its mostly forgotten women composers, Marcia J. Citron’s Gender and the Musical Canon (Cambridge: Cambridge University Press, 1993) stands out for its groundbreaking analysis of the agents by which females have been largely excluded as composers from the canons of Western art music.

82 Christopher St. John [Christabel Marshall], Ethel Smyth: A Biography (London: Longmans, 1959), 82n1.

83 On female composers active in England during this time period, see Sophie Fuller, "Women Composers during the British Musical Renaissance, 1880-1918” (PhD dissertation, King’s College, University of London, 1998), which includes case studies of White, Lehmann, Frances Allitsen [Mary Frances Bumpus] (1848-1912), Rosalind Ellicott (1857-1924), and 
two others to be introduced presently, Dora Bright and Adela Maddison. All six of these figures were born within ten years of Smyth. For some illuminating discussion of Smyth's silence over other women composers in her writings, and its wider historiographical implications, see ibid., 137-41. On Smyth’s relationship with the Society of Women Musicians (SWM), see Laura Seddon, "The Instrumental Music of British Women Composers in the Early Twentieth Century" (PhD dissertation, City University London, 2011), 77. Chaminade was herself president of the SWM in 1913-14; as a founding member, Clarke’s involvement with the Society predated her period of success as a composer, though my point nonetheless stands. See further, Laura Seddon, British Women Composers and Instrumental Chamber Music in the Early Twentieth Century (Farnham: Ashgate, 2013).

See Maude Valérie White, My Indian Summer: A Second Book of Memories (London: Grayson \& Grayson, 1932), 12. As noted above, no corresponding account of such a meeting is to be found in Smyth's writings. Her Sicilian tour of 1903 is briefly discussed in What Happened Next, 227-29.

86 See Sophie Fuller, The Pandora Guide to Women Composers: Britain and the United States 1629-Present (London: Pandora, 1994), 204.

87 Writing in January 1928, the date given for both the essay “A Final Burning of Boats” and the volume of the same title, Smyth would have had access to the first three volumes of the third edition of Grove's Dictionary (all published in 1927), in which an article on Maddison would have been found. Maddison's career may have been over by this time (she died in 
1929 following a prolonged period of illness), but she had not appeared in the dictionary's second edition (see n15) either. Other omissions included Dora Bright (1863-1951), a more established composer than Dorothy Howell by 1927, and probably also more historically significant; and the prolific but short-lived Morfydd Owen (1891-1918), much of whose music had then recently been published posthumously in a multivolume edition (1923-24). It was a title that engendered disapproval from Woolf, who deemed it "diffuse” and “facetious when you mean to be serious.” Woolf to Smyth, 6 June 1933, in Letters, 5:192.

89 See Smyth, "Female Pipings in Eden,” 3; see further, ibid., 6 and 55-56 for the continuation of and conclusion to the tale.

90 Marcus, “Thinking Back through Our Mothers,” 26.

91 Smyth, "Female Pipings in Eden,” 38.

92 Isaiah Berlin, The Hedgehog and the Fox: An essay on Tolstoy's view of history (London: Weidenfeld \& Nicolson, 1953). Berlin himself borrowed the terms from a fragment of ancient Greek poetry by Archilochus.

93 Woolf to Smyth, 6 December 1940, in Letters, 6:450. Woolf confessed to an "ulterior motive" in making this suggestion, namely her desire to "investigate the influence of music on literature" (ibid.). The final page of the letter was lost prior to publication, so it is not known how Woolf expanded upon her ideas.

94 Woolf, The Common Reader: First Series (see n5) and The Common Reader: Second Series (London: Hogarth, 1932).

95 Ethel Smyth, “Composers and Critics,” The New Statesman, 9 May 1931, 389-90. 
Woolf to Smyth, 27 June 1931, in Letters, 4:348.

Woolf to Smyth, 13 December 1937, in Letters, 6:191. From the present vantage point, it is difficult not to read resonances of Smyth's own deafness in Woolf's words, but this is presumably unintended. Woolf to Smyth, 24 February 1938, in Letters, 6:217, italics in original. See Smyth, "Female Pipings in Eden,” esp. 7-13, 46-49.

Upon reading an early draft of this essay, Woolf had written to the author that "I think its very good tempered, and urbane, and, if a little diffuse, still genial, undeniable, and full of truth, and facts. What facts!” Woolf to Smyth, 19 November 1933, in Letters, 5:249.

101 The vast majority of the correspondence from Smyth to Woolf has been lost; fewer than ninety items are held in The Henry W. and Albert A. Berg Collection, New York Public Library, of which some fifteen relate to the period 1938-41. But even if more comprehensive documentation were available yet no evidence of a written response from Smyth was evident, the possibility would remain that she had replied to her friend's request for information verbally. My suspicion, however, is that Woolf's questions remained unanswered, because Smyth surely would have furnished her with further detail on issues such as women’s admission to orchestras than ultimately appeared in Three Guineas.

102 Woolf, Three Guineas, 69-70.

103 Woolf, Three Guineas, 249-50.

104 This observation is given further weight by an additional reference to music in the endnotes for chapter 2: "Chastity was invoked to prevent her from studying medicine; from painting 
the nude; from reading Shakespeare; from playing in orchestras; from walking down Bond Street alone.” Woolf, Three Guineas, 298-99.

${ }^{105}$ In addition to those quoted elsewhere in my essay, passing mentions of music in Three Guineas include: in chapter 1, Woolf's proposition that a poor women's college in need of rebuilding would have to "teach only the arts that can be taught cheaply and practised by poor people; such as medicine, mathematics, music, painting and literature” (page 62), and that "Musicians, painters, writers, would teach there, because they would learn" (63); her suggestion that the nineteenth-century "educated man's daughter" living in her father's house might, in the winter months, have "studied history and literature and music, and tried to draw and paint” (69); in chapter 2, Woolf's engagement with the view that those professionals who achieve great success become so consumed with their work that they have "no time to look at pictures ... no time to listen to music ... [and] no time for conversation” (131); her observation that, irrespective of wealth, daughters of educated men may "Go to the public galleries and look at pictures; turn on the wireless and rake down music from the air; [and] enter any of the public libraries which are now free to all” (148); in chapter 3, three allusions to "pictures, plays, music and [or] books" (174), plus one to an unspecified "picture, symphony, play or poem” (175), in a discussion of how an educated man's daughter might formulate opinions of her own; a reference to a hypothetical space in which such a person might privately "speak the truth to artists, about pictures, music, books, without fear of affecting their sales” (178); and finally, Woolf's suggestion that the educated man's daughter might evaluate England's supposed superiority by “compar[ing] English painting with French 
painting; English music with German music; English literature with Greek literature” (19697).

${ }^{106}$ See above, $\mathrm{n} 5$ for citation.

${ }^{107}$ See William Weber, Music and the Middle Class: The Social Structure of Concert Life in London, Paris, and Vienna (London: Croom Helm, 1975), 31.

${ }^{108}$ Woolf's admiration for Austen and her work is clearly demonstrated in the extent of the discussion she received in her factual literature, not least in dedicated essays including "Jane Austen,” Times Literary Supplement, 8 May 1913; “Jane Austen Practising,” The New Statesman, 15 July 1922; and “Jane Austen,” The Common Reader: First Series, 168-83, repr. in Collected Essays by Virginia Woolf, [ed. Leonard Woolf], 4 vols. (London: Hogarth, 1966-67), 1:144-54. These writings are reprinted in The Essays of Virginia Woolf, ed. McNeillie, 2:9-16, 3:331-35, and 4:146-57, respectively. 109 [Jane Austen], Sense and Sensibility (London: Egerton, 1811), 3 vols.; Pride and Prejudice (London: Egerton, 1813), 3 vols.; Emma (London: Murray, 1816), 3 vols.; Northanger Abbey and Persuasion (London: Murray, 1818), 4 vols. On music in/and Austen’s novels see, for example, Patrick Piggott, The Innocent Diversion: A Study of Music in the Life and Writings of Jane Austen (London: Cleverdon, 1979).

110 Smyth, "Women’s Training Hitherto," chap. 2 of "Female Pipings in Eden,” 7-13. Woolf, of course, had the additional benefit of reading earlier drafts of this essay. 
111 The information presented in the remainder of this paragraph has been garnered from Smyth, Impressions that Remained, 1:38, 110-14, and 123-27, an account with which Woolf was certainly familiar.

112 Smyth, Impressions that Remained, 2:5.

113 Of many modern studies of women's autobiography, too numerous to cite here, that identify the necessity of expanding their scope of inquiry beyond traditional (androcentric) definitions of the term, the approach outlined above emerges particularly strongly in The Private Self: Theory and Practice of Women's Autobiographical Writings, ed. Shari Benstock (London: Routledge, 1988).

114 [Cardinal] John Henry Newman, D.D., Apologia pro vita sua: Being a Reply to a Pamphlet entitled “What, Then, Does Dr. Newman Mean?” (London: Longman, Green, Longman, Roberts, and Green, 1864, rev. and abr. in 1865 as History of My Religious Opinions). The pamphlet in question, Rev. Charles Kingsley's “What, Then, Does Dr. Newman Mean?”: A Reply to a Pamphlet Lately Published by Dr. Newman (London: Macmillan, 1864), was itself occasioned by Newman's publication of letters between them as Mr. Kingsley and Dr. Newman: A Correspondence on the Question Whether Dr. Newman Teaches that Truth is No Virtue? (London: Longman, Green, Longman, Roberts, and Green, 1864).

115 Jean-Jacques Rousseau's multivolume Les confessions, written in the 1760s and probably completed in 1770, was first published posthumously in the 1780s.

116 Woolf to Gerald Brenan, 4 October 1929, in Letters, 4:98.

117 Woolf to Smyth, 6 June 1933, in Letters, 5:191, 193; and 8 June 1933, in Letters, 5:194, 195. 
118 Virginia Woolf, “A Sketch of the Past,” in Moments of Being: Unpublished Autobiographical Writings, ed. Jeanne Schulkind, 2nd ed. (London: Hogarth, 1985), 64-159.

119 Hermione Lee, Virginia Woolf (London: Chatto \& Windus, 1996), 603.

120 Smyth, As Time Went On..., 4. 